\title{
Tingkat Stres dan Indikator Stres pada Remaja yang Melakukan Pernikahan Dini
}

\author{
Mega Nur Rahmawati ${ }^{1}$, Slamet Rohaedi ${ }^{2}$, Sri Sumartini ${ }^{3 *}$ \\ 1,2,3 Program Studi DIII Keperawatan Universitas Pendidikan Indonesia \\ *Email korespondensi: : srisumartini@upi.edu
}

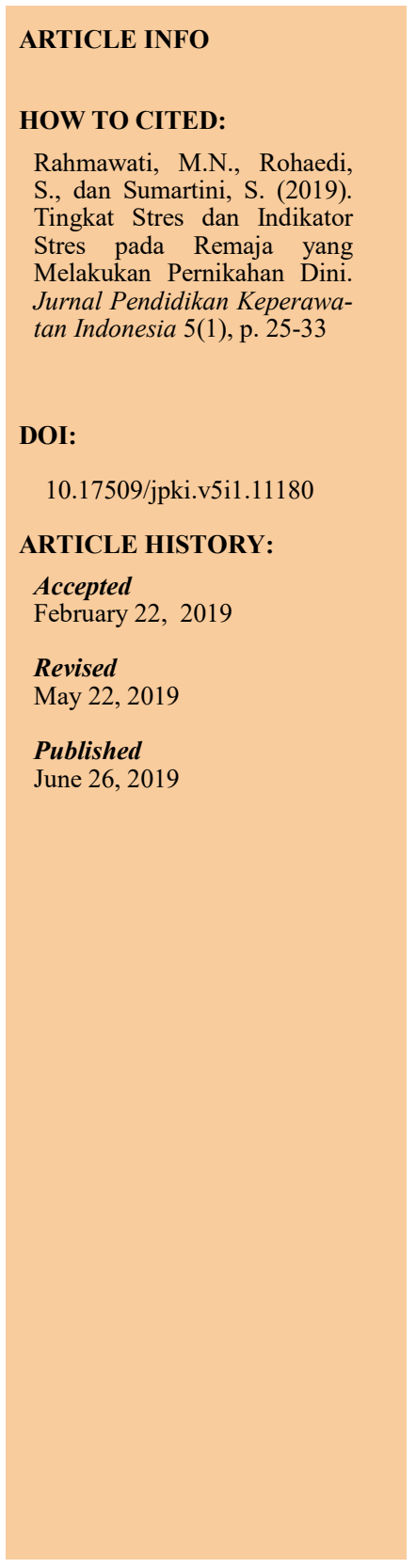

\section{A B S T R A K}

Remaja adalah individu yang sedang dalam tahap perkembangan transisi antara masa anak-anak dan masa dewasa awal, dimana pada ini terjadi banyak perubahan secara anatomis, fisiologis, fungsi emosional dan intelektual serta hubungan di lingkungan sosial. Pernikahan dini diartikan pernikahan yang pasangan masih muda dan belum memenuhi persyaratan untuk melakukan pernikahan. Usia Remaja yang melakukan pernikahan dini beresiko tidak dapat beradaptasi dengan baik dengan lingkungan dan situasi barunya sehingga beresiko menimbulkan stres. Gejala stress dapat menjadi masalah kesehatan yang cukup serius yang dapat berdampak secara psikologis, sosial dan ekonomi. Penelitian ini bertujuan mengidentifikasi tingkat stres dan indikator stress yang terjadi pada usia remaja yang melakukan pernikahan dini menggunakan metode deskriptif kuantitatif. Data diperoleh dengan menggunakan instrument kuesioner DASS-21. Sampel yang diteliti adalah pasangan remaja telah menikah pada usia 16-20 tahun sebanyak 104 pasangan yang diambil dengan menggunakan teknik purposive sampling. Hasil penelitian dianalisis menggunakan perhitungan distribusi frekuensi dan presentase (\%). Hasil penelitian didapatkan bahwa 46,1\% responden mengalami kondisi stres normal, $29 \%$ responden dalam keadaan stress ringan, $15,3 \%$ responden dalam keadaan stress sedang, $8,6 \%$ responden keadaan stress berat, dan $1 \%$ responden berada dalam keadaan stress sangat berat. Berdasarkan hasil penelitian ini, maka dapat disimpulkan bahwa secara psikologis, menikah pada usia dini beresiko menimbulkan suatu beban psikis bagi yang menjalaninya.

Kata kunci: Remaja, Pernikahan Dini, Stres

\section{$A B S T R A C T$}

Adolescents are individuals who are in the stage of developing transitions between childhood and early adulthood, where there are many changing in anatomical, physiological, emotional, and intellectual functions and relationships in the social environment. Early marriage is defined as a marriage in which the couple is young and has not met the requirements for marriage. The age of adolescents who do early marriages is at risk of not being able to adapt well to the environment and new situation so that it is at risk of causing stress. Stress symptoms can be a severe health problem that can have psychological, social, and economic impacts. This study aims to identify stress levels and stress indicators that occur in adolescents who conduct early marriages using quantitative descriptive methods. Data were obtained using the DASS-21 questionnaire. The sample studied was a pair of 
married teenagers at the age of 16-20 years, with 104 pairs taken using the purposive sampling technique. The results of the study were analyzed using the calculation of frequency distribution and percentage (\%). The results showed that $46.1 \%$ of respondents experienced normal stress conditions, $29 \%$ of respondents in mild stress conditions, $15.3 \%$ of respondents were in a state of moderate stress, $8.6 \%$ of respondents were severely stressed, and $1 \%$ of respondents were in a very stressful state weight. Based on the results of this study, it can be concluded that psychologically, getting married at an early age risk creating a psychological burden for those who live it.

Keywords: Adolescent, Early Marriage, stress

\section{PENDAHULUAN}

World Health Organization (WHO) (2014) mengungkapkan bahwa Remaja adalah suatu periode transisi dari masa awal anak anak hingga masa awal dewasa, yang dimasuki pada usia kira kira 12 tahun dan berakhir pada usia 18 tahun hingga 22 tahun. Pada masa ini remaja mengalami proses pematangan fisik yang lebih cepat dari pada pematangan psikososialnya dan semakin banyak menghabiskan waktu diluar keluarga.

Hurlock (2013) mengatakan bahwa dibandingkan dengan kelompok anak dan orangtua, masa remaja merupakan masa yang paling berat. Masa ini merupakan masa transisi dimana terjadi banyak perubahan, baik secara anatomis, fisiologis, fungsi emosional dan intelektual serta hubungan di lingkungan sosial.Yulianti (2010) menjelaskan bahwa sifat-sifat keremajaan ini, seperti, emosi yang tidak stabil, belum mempunyai kemampuan yang matang untuk menyelesaikan konflik-konflik yang dihadapi, serta belum mempunyai pemikiran yang matang tentang masa depan yang baik. Hal ini akan sangat memengaruhi perkembangan psikososial anak terutama dalam kemampuan pengelolaan konflik. Pernikahan dini adalah pernikahan yang dilakukan bila umur pria kurang dari 21 tahun dan umur perempuan kurang dari 19 tahun (Kumalasari, 2012; dan Janiwarty, 2013).

Usia remaja menimbulkan berbagai persoalan dari berbagai sisi seperti masa remaja yang selalu ingin coba-coba, pendidikan yang rendah, pengetahuan yang kurang, pekerjaan semakin sulit didapat sehingga berpengaruh pada pendapatan ekonomi keluarga (Manuaba: 2008). Faktor sosial yang terdiri dari gaya berpacaran remaja dan pergaulan remaja juga mendorong remaja dalam pernikahan di usia muda. Faktor lain yang tidak kalah besar pengaruhnya yakni faktor lingkungan. Lingkungan seperti orang tua, saudara dan kerabat, dan pergaulan dengan teman turut memberikan pengaruh dalam diri remaja juga turut mempengaruhi pernikahan usia muda (BKKBN : 2012).

Penelitian United Nations Children's Fund (UNICEF) tahun 2012 melaporkan bahwa sekitar 150 juta remaja di dunia menikah dibawah usia 16 tahun dan praktek pernikahan usia dini paling banyak terjadi di Asia Tenggara dan Afrika. Di Asia Tenggara didapatkan data bahwa sekitar 10 juta remaja dibawah 16 tahun telah menikah, sedangkan di Afrika diperkirakan 42\% dari populasi anak menikah sebelum mereka berusia 16 tahun (kumaidi: 2015).

Badan Pusat Statistik (BPS) jumlah remaja usia 10-19 tahun di Indonesia tahun 2012 memberikan informasi sebesar 41 juta penduduk dan tahun 2013 mencapai 62 juta jiwa. Data Badan Kependudukan Dan Keluarga Berencana Nasional (BKKBN) tahun 2012 pernikahan di bawah usia 16 tahun di Indonesia mencapai $25 \%$, bahkan pernikahan usia 12-14 tahun mencapai 20\%-35\% dari seluruh jumlah pernikahan yang ada. Pernikahan dini dibawah usia 16 tahun angkanya jauh lebih besar sekitar 47,79\% dan di perkotaan sekitar 21,75\% (Kumaidi: 2015).

Negara Indonesia termasuk yang persentase pernikahan usia mudanya tinggi di dunia yaitu menempatkan ranking ke 37 (BKKBN, 2012). Hal ini dikarenakan usia minimum menikah di Indonesia sekitar 16 tahun, seperti yang tercantum didalam undang-undang Republik Indonesia Nomor 1 tahun 1974 mengenai Perkawinan, 
pada pasal 7 menyebutkan bahwa usia minimal seorang wanita diizinkan menikah adalah 16 tahun. Namun Badan Koordinasi Keluarga Berencana Nasional (BKKBN, 2012) memberikan peringatan bahwa wanita sebaiknya menikah di atas usia 20 tahun dan pria pada 25 tahun, karena pada umumnya pasangan yang menikah muda emosinya cenderung menggebu-gebu dan lebih mudah menghadapi stres.

Pada saat ini permasalahan yang terjadi di Indonesia yaitu kasus pernikahan dini di kalangan remaja semakin banyak terjadi. Berdasarkan Survei Data Kependudukan Indonesia (SKDI) 2012, di beberapa daerah didapatkan bahwa sepertiga dari jumlah pernikahan terdata dilakukan oleh pasangan usia di bawah 16 tahun, Jumlah kasus pernikahan dini di Indonesia terutama di Jawa Timur, Kalimantan Selatan, Jambi dan Jawa Barat, angka kejadian pernikahan dini berturut-turut $39,4 \%, 35,5 \%, 30,6 \%$ dan $36 \%$ mencapai 50 juta penduduk dengan rata-rata usia pernikahan 19,1 tahun. Badan Koordinasi Keluarga Berencana Nasional (BKKBN, 2013) rata-rata usia pernikahan dini di Jawa Barat adalah 18,05 tahun, hal itu masih di bawah standar usia pernikahan berdasarkan kesehatan reproduksi wanita, usia perempuan untuk menikah itu minimal 21 tahun (m.tempo.co : 2016).

Riset Kesehatan Dasar (Riskesdas) tahun 2010, Perempuan muda di Indonesia yang menikah menurut umur pernikahan pertama paling tinggi sebanyak $41,9 \%$ berusia $15-19$ tahun sedangkan paling rendah sebanyak $0,6 \%$ berusia 35 tahun ke atas. Undang-undang perkawinan menyebutkan bahwa batas minimal perkawinan seseorang adalah berusia 19 tahun untuk lakilaki dan 16 tahun untuk perempuan. Akan tetapi jika mengacu pada UU Perlindungan Anak No. 23 tahun 2002 perkawinan usia 18 tahun ke bawah termasuk pernikahan dini (Lestari: 2015).

Masalah yang terjadi lainnya pada pernikahan dini juga dapat dikarenakan belum cukupnya kesiapan dari berbagai aspek diantaranya aspek kesehatan, mental emosional, pendidikan, sosial, ekonomi, dan reproduksi (Depkes, 2015). Hasil penelitian Ermawan (2014) mengatakan bahwa remaja yang menikah dini dilaporkan mengalami gangguan kesehatan mental. Mereka tidak dapat mengendalikan emosi dan mengelola stres. Remaja yang melakukan pernikahan tidak dapat beradaptasi dengan baik dengan lingkungan dan situasi barunya maka beresiko mengakibatkan timbulnya stres (Rohayati, 2017). Stres yang berkepanjangan akibat pernikahan yang tidak diinginkan atau belum waktunya (unwanted or mistimed ) akan mempengaruhi konsep diri seorang remaja, konsep diri yang negatif akan berdampak pada sikap dan prilaku (Hawari, 2011).

Pernikahan dini dalam hal ini berpengaruh pada tingkat stress remaja. Hasil penelitian Rohmah (2014) Ketidaksiapan dalam memasuki kehidupan perkawinan diangap menjadi indikator kerentanan munculnya stres. Hasil penelitian Khusnah pada tahun 2010 menyebutkan remaja wanita yang menikah dini mengalami stres sedang. Usia yang masih relatif muda menjadikan pemikiran yang belum matang seutuhnya namun dituntut untuk melakukan pernikahan. Mereka merasa stres ketika harus memiliki keluarga dan menjadi orang tua di usia yang masih relatif muda, ibu muda cenderung mudah stres (Rohayati, 2017). Sesuai dengan penelitian yang telah dilakukan Rahayu, dkk (2012) yang menyebutkan bahwa semakin tinggi kesiapan untuk menikah, maka semakin rendah tingkat stres yang dihadapi. Perasaan mampu dari seseorang yang memiliki kepercayaan dirinya untuk menanggulangi stres merupakan faktor utama dalam menentukan kerasnya stres (Sriati, 2008).

Hasil dari studi pendahuluan, menurut Kantor Pengadilan Kementerian Agama Kabupaten Bandung Barat mencatat hasil pernikahan dini rata-rata di seluruh kecamatan masih tergolong tinggi, bahkan untuk Kecamatan Lembang, parongpong, dan Padalarang angka pernikahan dibawah usia 20 tahun masih tinggi (RmolJabar.com). Angka pernikahan dini Kabupaten Bandung Barat di tahun 2015 dan 2016 pernikahan usia dibawah 19 tahun mencapai 12.643 perkawinan, tahun 2015 angka perkawinan dini berjumlah 7.884 dan 2016 berjumlah 4.759 perkawinan, di Kecamatan Parongpong tercatat dalam tahun 2015 berjumlah 135 orang, di tahun 2016 berjumlah 142 orang, dan 3 bulan 
terakhir di awal 2017 berjumlah 50 orang. Tingginya angka pernikahan dini menunjukan terjadinya permasalahan sosial dan psikososial pada remaja akan cenderung meningkat (Noorkasiani, Heryati \& Rita Ismail, 2009).

\section{METODE PENELITIAN}

Desain yang digunakan dalam penelitian ini adalah deskriptif kuantitatif menggunakan populasi sebanyak 142 orang. Teknik sampling yang digunakan adalah purposive sampling dengan besar sampel yang diteliti sebanyak 104 orang pasangan remaja dengan kriteria inklusi yaitu: Pasangan telah menikah, berusia 16-20 tahun, dan berdomisili di Wilayah Kerja Puskesmas Parongpong, Pasangan remaja yang bersedia mengisi kuesioner. Sementara kriteria eksklusi yaitu Pasangan remaja yang telah bercerai.

Instrumen penelitian yang digunakan adalah kuesioner DASS 21 (Depression Anxiety Stress Scale) yang dikembangkan oleh Lovibond. S. H dan Lovibond. P. H (1995). Instrumen DASS 21 terdiri dari 21 item pertanyaan, yang mencangkup 3 subvariabel diantaranya fisik, emosi/psikologis dan perilaku (Crawford \& Henry, 2005). DASS 21 berisi pertanyaan yang singkat sehingga bisa disesuaikan dengan subjek penelitian yang berkisar antara usia 16-20 tahun. Hasil penelitian didapatkan dengan menggunakan analisis data distribusi frekuensi dan presentase $(\%)$.

\section{HASIL PENELITIAN}

Informasi yang didapatkan berdasarkan hasil penelitian tingkat dan indikator stress pada remaja yang melakukan pernikahan dini yang telah dilaksanakan di wilayah kerja Puskesmas Parongpong Kabupaten Bandung Barat dapat dilihat pada Tabel 1.

\section{Gambaran Karakteristik Responden}

Pada penelitian ini terdapat beberapa karakteristik subjek penelitian untuk memperjelas hasil penelitian. Data karakteristik demografi responden diantaranya adalah usia, dan pendidikan.
Usia berkaitan dengan toleransi seseorang terhadap stres. Pada usia remaja seringkali rawan terhadap stres dan emosinya sangat kuat namun dari tahap remaja awal ke remaja akhir terjadi perbaikan pada perilaku emosionalnya dan lebih mampu mengontrol stres. Menurut Kumalasari (2012) tentang perkembagan remaja dibagi menjadi tiga tahap yang pertama tahap remaja awal usia 10-12 tahun, yang kedua remaja pertengahan usia 13-15 tahun, dan yang ketiga remaja akhir 16-19 tahun. Pada peneliti ini menggunakan teori usia remaja akhir dari usia 16-20 tahun. Dari data karakteristik responden berdasarkan usia, sebagian besar berada pada kelompok usia 20 tahun berjumlah 28 orang (27\%), setengah kecil dari responden yang memiliki usia 19 tahun berjumlah (26\%), hampir sebagian kecil dari responden yang memiliki usia 18 tahun $(19,2 \%)$, sebagian kecil dari responden 17 tahun $(16,3 \%)$, dan sebagian sisa responden yang memiliki usia 16 tahun $(11,5)$. Responden terbanyak berusia 20 tahun yang termasuk dalam kategori remaja akhir. Hal ini sesuai dengan teori tugas perkembangan Hurlock (2013) dimana tugas perkembangan dari remaja akhir yaitu mampu menerima dan memahami peran seks usia dewasa, mencapai kemandirian emosional dan ekonomi, mengembangkan tanggung jawab sosial yang diperlukan untuk memasuki dunia dewasa. Sehingga dapat dinyatakan bahwa semakin bertambahnya usia, semakin dirinya mampu beradaptasi dengan situasi dan memiliki toleransi baik terhadap stresor.

Pendidikan sering dilihat sebagai kunci untuk mencegah pernikahan dini (UNICEF,2005). Presentase pernikahan usia dini akan menurun apabila tingkat pendidikan yang diraih seorang perempuan semakin tinggi. Sejalan dengan hasil penelitian Rafidah, dkk (2009) yang menyebutkan pendidikan yang rendah beresiko 2,9 kali lebih besar untuk menikah pada usia kurang dari 20 tahun dibandingkan dengan yang berpendidikan tinggi. Data karakteristik berdasarkan pendidikan responden lebih dari setengahnya responden berpendidikan terakhir SMP sebanyak (54,8\%), hampir setengah dari responden berpendidikan SMA sebanyak $(39,4 \%)$, dan sebagian kecil dari responden berpendidikan SD 
sebanyak (5,7\%). Hal ini pendidikan responden berada dalam tingkatan SMP.Berdasarkan hasil penelitian Siboro (2009) menyebutkan bahwa tingkat pendidikan tidak berpengaruh pada tingkat stres karena tingkat pendidikan berhubungan dengan peran penting dalam perkembangan individu bukan dengan stres. Saat diwawancarai, kebanyakan dari responden lebih memilih untuk menikah dan tidak melanjutkan pendidikan ke tingkat yang lebih tinggi. Mereka merasa sudah siap dan percaya bahwa dirinya mampu untuk menjalankan peran sebagai seorang istri dan seorang ibu. Sesuai dengan penelitian yang telah dilakukan Rahayu, dkk (2012) yang menyebutkan bahwa semakin tinggi kesiapan untuk menikah, maka semakin rendah tingkat stres yang dihadapi. Perasaan mampu dari seseorang yang memiliki kepercayaan dirinya untuk menanggulangi stres merupakan faktor utama dalam menentukan kerasnya stres (Sriati, 2008).

\section{Gambaran Tingkat Stres Pada Pasangan yang Melakukan Pernikahan Dini}

Hasil penelitian menggambarkan secara umum pasangan yang melakukan pernikahan dini di wilayah kerja Puskesmas Parongpong Kabupaten Bandung Barat memiliki tingkat stres dalam rentang normal $(46,1 \%)$, stres normal merupakan bagian alamiah dari kehidupan yang hampir seluruh manusia mengalaminya yang memerlukan penyesuaian untuk menghadapi stresor (Crawford, R. J \& Henry, D. J. (2005). Stres ringan menduduki presentasi terbanyak kedua setelah stres normal yaitu sebanyak (29\%), pada stres ringan stresor yang dihadapi bisa berlangsung beberapa menit atau jam, stres ringan sering terjadi pada kehidupan sehari-hari dan kondisi ini dapat membantu seseorang menjadi waspada dan bagaimana mencegah berbagai kemungkinan yang akan terjadi. Stres ini tidak merusak aspek fisiologis seseorang, namun pada respon psikologi seseorang didapatkan merasa mampu menyelesaikan pekerjaan lebih dari biasanya, namun secara tidak disadari cadangan energi semakin menipis, stres ringan ini berada pada tahapan stres tahapan 1 dan II (Crawford,
R. J \& Henry, D. J. (2005). Stres sedang sebanyak (15,3\%), stres sedang berlangsung beberapa jam sampai beberapa hari. Stressor ini dapat menimbulkan gejala yaitu mudah merasa letih, mudah marah, sulit untuk beristirahat, mudah tersinggung, gelisah, stres sedang ini berada pada tahapan stres tahapan III (Psychology Foundation of Australia, 2010). Stres berat sebanyak $(8,6 \%)$, stres berat merupakan situasi kronis yang dapat terjadi dalam beberapa minggu, persepsi individu sangat menurun dan cenderung membutuhkan banyak pengarahan, stres berat ini berada pada tahapan stres tahapan IV (Crawford, R. J \& Henry, D. J. (2005). Stres sangat berat $(1 \%)$, stres sangat berat merupakan situasi kronis yang dapat terjadi dalam beberapa bulan dan dalam kurun waktu yang tidak dapat ditentukan, biasanya seseorang dalam tingkat stres sangat berat cenderung pasrah dan tidak memiliki motivasi untuk hidup. Seseorang dalam tingkatan stres ini biasanya teridentifikasi mengalami depresi berat kedepannya, stres sangat berat ini berada pada tahapan stres tahapan V dan VI (Psychology Foundation of Australia, 2010).

Berdasarkan teori (Stuart \& Sundeen, 1998; Hamid, S \& Achir Yani, 2009 ) hasil yang di dapatkan pasangan remaja yang melakukan pernikahan dini hampir setengah dari responden memiliki rentang respon adaptif dimana respon tersebut individu mampu menyelesaikan masalah yang masih dapat diterima oleh norma sosial dan budaya yang umumnya berlaku, dengan kata lain individu tersebut masih dalam batas-batas normal saat menyelesaikan masalah. Sedangkan setengah dari responden memiliki rentang respon mal adaptif diman respon tersebut menyimpang dari norma-norma social dan budaya lingkungan, sehingga di dapatkan pasangan remaja tidak mampu mengatasi konflik-konflik yang terjadi pada rumah tangganya.

Stres yang normal, menunjukkan bahwa hampir setengah dari responden mempunyai sistem adaptasi atau penyesuaian baik yang berhubungan dengan dukungan, baik dalam diri sendiri, keluarga, maupun lingkungan sosial. Pengaruh lingkungan dan sosial dapat membantu seseorang dalam menghadapi stres. Sesuai 
Rahmawati, M.N., Rohaedi, S., dan Sumartini, S | Tingkat Stres dan Indikator Stres pada Remaja yang Melakukan Pernikahan Dini

Tabel 1. Distribusi frekuensi karakteristik demografi responden pasangan usia dini

\begin{tabular}{ccc}
\hline & Karakteristik & \\
\hline Usia & Frekuensi & Presentasi \\
\hline 16 & 12 & $11,5 \%$ \\
17 & 17 & $16,3 \%$ \\
18 & 20 & $19,2 \%$ \\
19 & 27 & $26 \%$ \\
20 & 28 & $27 \%$ \\
\hline Pendidikan & Frekuensi & Presentasi \\
\hline SD & 6 & $5,7 \%$ \\
SMP & 57 & $54,8 \%$ \\
SMA & 41 & $39,4 \%$ \\
\hline
\end{tabular}

Tabel 2. Distribusi frekuensi tingkat stres pada pasangan usia dini

\begin{tabular}{ccc}
\hline Tingkat Stres & Frekuensi & Presentase\% \\
\hline Normal & 48 & 46,1 \\
Ringan & 30 & 29 \\
Sedang & 16 & 15,3 \\
Berat & 9 & 8,6 \\
Sangat Berat & 1 & 1 \\
\hline Total & 104 & 100 \\
\hline
\end{tabular}

Tabel 3. Distribusi frekuensi indikator stres pada pasangan usia dini

\begin{tabular}{lcc}
\hline \multicolumn{1}{c}{ Indikator } & Frekuensi & Presentase \\
\hline Sulit beristirahat & 90 & 86,5 \\
Reaksi berlebihan & 79 & 76 \\
Gugup & 87 & 84 \\
Gelisah & 83 & 79,8 \\
Sulit tenang & 83 & 79,8 \\
Memaklumi gangguan & 76 & 73 \\
Mudah Tersinggung & 91 & 87,5 \\
\hline
\end{tabular}


dengan teori bahwa stres merupakan bagian kehidupan suatu individu, sehingga menuntut individu untuk beradaptasi, adaptasi melibatkan mekanisme untuk perlindungan, mekanisme koping, dan dapat mengarahkan pada penyesuaian dan penguasaan situasi (Khairunnisa, D. oktavia, 2016). Hasil penelitian Khoiyriyyatul (2014) yang menyebutkan bahwa terdapat hubungan antara strategi koping stres dengan penyesuaian pernikahan remaja.

\section{Gambaran Indikator Stres pada Pasangan Usia Dini}

Pada penelitian ini terdapat karakteristik indikator penelitian untuk memperjelas hasil penelitian, pasangan yang merasakan stres dengan gejala-gejala negatif. Hasil data karakteristik terhadap pasangan yang melakukan pernikahan dini di wilayah kerja Puskesmas Parongpong Kabupaten Bandung Barat gejalagejalanya sebagai berikut, sebanyak $(87,5 \%)$ pasangan remaja yang mudah tersinggung, sulit beristirahat $(86,5 \%)$, merasa gugup $(84 \%)$, gelisah $(79,8 \%)$, sulit untuk bersikap tenang (79,8\%), mengalami reaksi berlebihan (76\%), dan yang terakhir $(73 \%)$ tidak bisa memaklumi gangguan yang ada di sekitarnya. Faktor yang mempengaruhi stres adalah faktor lingkungan fisik, tertekan di lingkugan tersebut, dan ketidaknyamanan lingkugan faktor fisiologis, perubahan kondisi tubuh masa remaja misalnya kehamilan serta reaksi tubuh terhadap ancaman dan perubahan lingkungan, faktor psikologis, perselingkuhan dan perceraian, dan masalah sehari-hari (Hawari, 2011). Menurut Hawari (2011) Gejala fisiologis antara lain jantung berdebar-debar, muka pucat, gangguan gastrointestinal, gangguan pernafasan, gangguan pada kulit (timbul jerawat, kedua telapak tangan dan kaki berkeringat), sering buang air kecil, mulut dan bibir terasa kering, sakit kepala, sakit pada punggung bagian bawah, ketegangan otot serta gangguan tidur. Sebagian kecil responden mengalami gejala stres fisiologis dilihat dari gejala fisiologisnya, hal ini ditunjukkan dengan responden yang mengalami jantung berdebardebar, muka pucat pada saat memiliki tuntutan beban kepada individu tersebut dan tidak sanggup untuk mengatasi beban tersebut. Hal yang paling ekstrim mengenai dampak psikologis misalnya rasa cemas yang berlebihan, merasa ketakutan, depresi dan munculnya gejala stres. Seseorang yang mengalami gejala stres dapat dilihat baik secara psikologis.

Hal ini sesuai dengan hasil penelitian dari Ermawan, 2014 yang mengatakan bahwa responden yang mengalami gangguan kesehatan mental ini lebih mengarah pada gangguan penurunan energi, cemas, dan gangguan somatik. Jika dilihat dari sudut pandang responden mengalami gangguan penurunan energi dapat dilihat dari pertumbuhan dan perkembangan remaja. Dengan pernikahan dini ini maka remaja mengalami gangguan secara psikologi dipengaruhi belum mampu beradaptasi terhadap hal baru, lingkungan baru.

\section{SIMPULAN}

Berdasarkan hasil penelitian ini dapat disimpulkan bahwa setengah dari responden dikelompokan dalam keadaan stres normal, hampir setengahnya dari responden dikelompokan dalam keadaan stres ringan, sebagian kecil dari responden dikelompokan dalam keadaan stres sedang, sebagian kecil dari responden dikelompokan dalam keadaan stres berat, dan sebagian kecil dari responden dikelompokan dalam keadaan stres sangat berat.

Hasil yang didapatkan pasangan remaja yang melakukan pernikahan dini hampir setengah dari responden memiliki rentang respon adaptif dimana respon tersebut individu mampu menyelesaikan masalah yang masih dapat diterima oleh norma sosial dan budaya yang umumnya berlaku, dengan kata lain individu tersebut masih dalam batas-batas normal dalam menyelesaikan masalah. Sedangkan setengah dari responden memiliki rentang respon mal adaptif dimana respon tersebut menyimpang dari norma-norma social dan budaya lingkungan, sehingga di dapatkan pasangan remaja tidak mampu mengatasi konflik-konflik yang terjadi pada rumah tangganya, dan memiliki gejalagejala sebagai berikut: banyak pasangan remaja yang mudah tersinggung, sulit beristirahat mera- 
sa gugup, gelisah sulit untuk bersikap tenang, mengalami reaksi berlebihan, dan yang terakhir tidak bisa memaklumi gangguan yang ada di sekitarnya.

Secara psikologis menikah pada usia dini merupakan suatu beban psikis, karena berumah tangga dan menjaga keharmonisannya bukan

\section{DAFTAR PUSTAKA}

Agustini, N. N. M., \& Arsani, N. L. K. A. (2013). Remaja Sehat Melalui Pelayanan Kesehatan Peduli Remaja di Tingkat Puskesmas. Jurnal Kesehatan Masyarakat vol. 9 (1). https://journal.unnes.ac.id/nju/ index.php/kemas/article/view/2832.

Arikunto, Suharsimi. (2013). Prosedur Penelitian Suatu Pendekatan Praktik. Jakarta : Rineka Cipta.

Aminudin. A. S. (2016). Rata-rata Perempuan di Jawa Barat Menikah Umur 18 Tahun. m.tempo.co. Diperoleh dari https: // m.tempo.co/read/ news/2016/11/10/058819181/rata-rataperempuan-di-jawa-barat-menikah-umur18tahun. 10 November 2016

Astuty, S. Y. (2013). Faktor-Faktor Penyebab Terjadinya Perkawinan Usia Muda Dikalangan Remaja Di Desa Tembung Kecamatan Percut Sei Tuan Kabupaten Deli Serdang. Welfare State.

BKKBN. (2012). Kajian Pernikahan Dini pada Beberapa Provinsi di Indonesia: Dampak overpopulation, Akar Masalah dan Peran Kelembagaan di Daerah. Jakarta

BPS, BKKBN, \& Kemenkes. (2013). Survei Demografi dan Kesehatan Indonesia 2012 Kesehatan Reproduksi Remaja. Jakarta.

Crawford, R. J \& Henry, D. J. (2005). The Short -form Version Of The Depression Anxiety Stres Scales (DASS 21) : Construct Validity And Normative Data In A Large NonClinical Sample. British Journal Of Clinical Psychology 44, 227-238.

Depkes RI. (2015). Kumpulan Materi Kesehatan Reproduksi Remaja. Jakarta: Departemen Kesehatan.

Ermawan, H. (2014). Status Kesehatan mental suatu pekerjaan yang mudah, memerlukan kedewasaan dalam berfikir dan bertindak. Oleh karena itu batasan usia yang layak diperlukan untuk melaksanakan pernikahan guna untuk kesiapan secara mental dan kematangan secara fisik.

Remaja Nikah Muda di Desa Tambak Agung Puri Mojokerto. Laporan penelitian. 31 Mei 2014

Fausiah, F \& Widury, J. (2007). Psikologi Abnormal. Jakarta:UI-Press.

Hawari D, (2011). Manajemen Stres Cemas dan Depresi. Cetakan Ketiga, Ed. Kedua, Jakarta: FKUI.

Hamid, S, Achir Yani. (2009). Asuhan Keperawatan Kesehatan Jiwa. Bunga Rampai, EGC, Jakarta

Hurlock. (2013). Perkembangan Anak. jilid 1. Jakarta: Erlangga.

Janiwarty, B. Pieter, H, Z. (2013). Pendidikan Psikologi Untuk Bidan. Yogyakarta.

Jahja, Yudrik. 2012. Psikologi Perkembangan. Jakarta: Kencana.

Junari, T. (2017). Angka Pernikahan Dini di Bandung Barat Masih Tinggi. Rmoljabar. Diperoleh dari http://www.rmoljabar.com / $\mathrm{read} / 2017 / 02 / 22 / 36154 /$ Pernikahan-Dini-di -Bandung-Barat-Masih-Tinggi. 17 Januari 2017

Kumaidi, Amperaningsih, Y. (2015). Hubungan Sikap dan Status Ekonomi Dengan Pernikahan Dini Pada Remaja Putri. Jurnal Keperawatan. Volume XI (I). April 2015. 7580

Kumalasari, I. Andhyantoro, A. (2012). Kesehatan Reproduksi. Jakarta: Salemba Medika.

Khairunnisa, D. Oktavia, H. . S. (2016). Tingkat stres pada remaja wanita yang menikah dini di kecamatan babakan Cikao Kabupaten Purwakarta. IV(2), 67-76.

Lestari, P.R. (2015). Hubungan Antara Pernikahan Usia Remaja Dengan Ketahanan Keluarga. Jurnal Kesejahteraaan Keluarga dan Pendidikan. Volume V (1). Oktober 
2015. $18-25$

Marmi. (2014). Kesehatan Reproduksi. Yogyakarta: Pustaka Pelajar.

Manuaba, IG. (2008). Memahami Kesehatan Reproduksi. Jakarta : EGC.

Noorkasiani, Heryati \& Rita Ismail. (2009). Sosiologi Keperawatan. Jakarta. EGC.

Notoadmodjo, S. (2012). Metodologi Penelitian Kesehatan. Jakarta: RinekaCipta.

Nursalam. (2013). Metodologi Penelitian Ilmu Keperawatan: Pendekatan Praktis. Edisi 3. Jakarta : Salemba Medika.

Oswalt ,A. (2010). An Introduction to Adolescent Development. (online). Tersedia: (http://www.mentalhelp.net/poc/ view_doc.php?type $=$ doc $\& i d=41149 \& \mathrm{cn}=$ 131024 maret 2012).

Papalia, Diane, Old, S. W., Feldman, R. D. (2008). Psikologi Perkembangan. Jakarta: Kencana Prenada Media Grup.

. Polinggapo, Sri W, (2013). Perbedaan Tingkat Stres Remaja Berdasarkan Tipe Kepribadian Somatotype Sheldon. (skripsi). Fakultas Pendidikan Psikologi jurusan psikologi, Universitas Negeri Malang.

Psychology Foundation of Australia. 2010. Depression Anxiety Stress Scale. Http:// www.psy.unsw.edu.au. (diakses pada tanggal 22 Mei 2016)

Rohayati, R. (2017). Faktor Yang Berhubungan Dengan Perkembangan Sosial Emosi Anak. Jurnal Keperawatan.
Sarwono, S, W. (2013). Psikologi Remaja. Jakarta: RajawaliPers.

Sarafino, P.E \& Smith, W. T.( 2012). Health Psychology : Biopsychosocial Interactions. Asia : Wiley.

Setiadi (2013). Praktek Penulisan Riset Keperawatan. Edisi 2. Yogyakarta, Graha Ilmu.

Sriati, A (2008). Tinjauan Tentang Stres. Fakultas Ilmu Keperawatan. UNPAD. Jatinangor.

Stroudm L, R., Foster, E., Papandonatos, G.D., Handwerger, K., Granger, D. A., Kivlighan, K. T., \& Ninaura, R. (2009). Stress response and the adolescent transition: Performance versus peer rejection stressors. Development and psychopathology, 21(01), 47-68.

Sugiyono. (2012). Metode Penelitian Kuantitatif, Kualitatif, dan Kombinasi (Mixed methods) . Bandung: ALFABETA.

Suparyanto. (2013). Pernikahan Usia Muda. Tersedia di http://www.drsuparyanto / konsep pernikahandini. Diakses pada tanggal 16 Juli 2013.

Universitas Pendidkan Indonesia. (2015). Pedoman Penulisan Karya Tulis Ilmiah. Bandung. UPI Pres.

Widyastuti, Y. Rahmawati A. Purwaningrum, Y, E. (2009). Kesehatan Reproduksi. Yogyakarta: Penerbit Fitramaya. 